\title{
Nutritional profile and obesity: results from a random-sample population-based study in Córdoba, Argentina
}

\author{
Laura R. Aballay ${ }^{1} \cdot$ Alberto R. Osella $^{2} \cdot$ Ana G. De La Quintana ${ }^{3} \cdot$ \\ María del Pilar Diaz ${ }^{1}$
}

Received: 2 September 2014 / Accepted: 17 March 2015

(C) Springer-Verlag Berlin Heidelberg 2015

\begin{abstract}
Introduction Obesity is a chronic, heterogeneous, multifactorial disease, which has sharply increased in prevalence in both developed and developing countries. This study aimed to estimate the prevalence of obesity and to identify socio-demographic risk factors associated with it, with special emphasis on diet.

Methods Nutritional status, demographic characteristics, lifestyle habits, and food consumption patterns derived from a Food Frequency Questionnaire were investigated. Exhaustive exploratory analyses were performed in order to describe dietary patterns, and logistic regression models were used for odds ratio estimation.

Results The study included 4328 subjects, over 18 years old and resident in Cordoba city. The prevalence of overweight and obesity was 34 and $17 \%$, respectively, with $60 \%$ in men and $45 \%$ in women of BMI $\geq 25$. Obesity
\end{abstract}

María del Pilar Diaz

pdiaz@fcm.unc.edu.ar

Laura R. Aballay

laballay@fcm.unc.edu.ar

Alberto R. Osella

arosella@irccsdebellis.it

Ana G. De La Quintana

anadelaquintana7@gmail.com

1 Statistics and Biostatistics Unit, School of Nutrition, Faculty of Medical Sciences, National University of Córdoba,

Enrique Barros esq. Enfermera Gordillo, Ciudad

Universitaria, 5000 Córdoba, Argentina

2 Laboratorio di Epidemiologia e Biostatistica, IRCCS Saverio de Bellis, Via Turi, 27, 70013 Castellana Grotte, Bari, Italy

3 School of Nutrition, Faculty of Medical Sciences, National University of Córdoba, Enrique Barros esq. Enfermera Gordillo, Ciudad Universitaria, 5000 Córdoba, Argentina risk factors were high intake of sodium, refined grains, starchy vegetables, and snacks. A lower risk of overweight and obesity was associated with an adequate, moderate intake of meats, eggs, alcoholic beverages, sugar and sweets, milk, yogurt, and pulses.

Conclusions A high intake of snacks, refined grains, starchy vegetables and sodium and low intake of yogurt, milk, pulses, and whole grains seem to be associated with the emergence and high prevalence of obesity in Cordoba, Argentina.

Keywords Overweight - Obesity · Argentina ·

Odds ratio $\cdot$ Logistic regression
Abbreviations
OR Odds ratio
METs Metabolic equivalent of tasks
FFQ Food Frequency Questionnaire
LR Logistic regression
BMI Body Mass Index
IL Instruction level
SES Socio-economic status

\section{Introduction}

Obesity is a chronic, heterogeneous, multifactorial disease with an increase in fat/lean ratio, frequently accompanied by an increase in body weight, the magnitude and distribution of which conditions health [1]. Although the genetic component cannot be denied, it is unlikely to be the factor that explains its recent higher global prevalence, not only in developed but also in developing countries. There is a complex interaction between genes and environmental factors, such as dietary habits and physical activity, which influence 
its high prevalence. Examples of these are the great consumption of processed foods outside the home, high-energy foods, with a low concentration of micronutrients, rich in saturated fats as well as refined carbohydrates [2-6].

The phenomenon of dietary change worldwide has been called nutritional transition. According to a World Health Organization-Food and Agriculture Organization (WHOFAO) report, changes in lifestyle and diet, together with sedentarism and less physical activity, have affected health and nutrition [5]. Food intake in general is related to habits, which are influenced by the family's purchasing power. Socio-economic status (SES) as well as education level influence the selection and preferences in food according to the social and environmental situation.

Overweight and obesity are the fifth leading risk factor for death in the world [7]. It is estimated that 1.46 billion adults (1.41-1.51 billion) worldwide had a BMI of $25 \mathrm{~kg}$ / $\mathrm{m}^{2}$ or higher, of whom 205 million men (193-217 million) and 297 million women (280-315 million) were obese [8]. The prevalence of overweight/obesity in Córdoba, Argentina, has been recently published, including its association with some social and cultural factors, but a characterization of dietary habits is still lacking.

Obesity is also a public health issue in Córdoba Argentina [9]. Its population, which has a monotonous diet with an unusually high consumption of mainly barbecued red meat and a low fiber intake, as reported by Pou et al. [10, 11], constitutes an interesting scenario to perform studies in the field of the nutritional epidemiology of chronic diseases. The aim of this cross-sectional population-based random-sample study is to estimate an updated prevalence of overweight/obesity, to characterize Córdoba population's diet, and to identify an association between diet and overweight/obesity. We hypothesized that the prevalence of overweight and obesity in the population of Córdoba is associated with a high intake of fats and calories and a low consumption of vegetables, fruits, and fibers.

\section{Methods}

\section{Design and participants}

Details of the general design of the study have been published elsewhere [9]. Briefly, a random-sample population-based study, the Córdoba Obesity and Diet Study (CODIES), was conducted in Córdoba, the capital city of the state of Córdoba (located in the center of Argentina). According to the last census, Córdoba city has a population of about 1,300,000 inhabitants and is the second largest city in Argentina.

The survey was conducted from January 2005 to December 2012, and a multistage population random sample was drawn. Using socio-economic indicators of the National Institute of Statistics and Census (INDEC), the city was divided into 12 homogeneous blocks. Then barrios, blocks, and streets on the blocks were randomly drawn, and finally, one to five houses in the street were selected. All participants were 18 years old or older. As suggested by a study of obesity in Latin American countries [12], sample size was calculated for a hypothetical overweight prevalence of $35 \%$ with a probabilistic type I error $<0.05$ and a type II error of 0.10 . Sample size was estimated to be 4567 subjects.

All participants gave informed consent prior to their inclusion in the study. The study was approved by the Ethical Committee of the Faculty of Medical Sciences, University of Córdoba, and was performed in accordance with the ethical standards laid down in the 1964 Declaration of Helsinki.

Demographic characteristics and lifestyle habits of the participants were probed through ad hoc questionnaires, and anthropometric measurements were taken directly. Dietary habits were probed by means of a recently validated Food Frequency Questionnaire, which includes qualitative and quantitative information on food intake [13]. Participants were asked to indicate the frequency they had eaten each particular item over the previous 12 months and the portion size (three categories: small, medium and large). For single-unit items (such as slices of bread or non usual foods), participants were asked to state how many units were eaten on each occasion. Three-dimensional portion size images or a validated photographic atlas based on standard portion sizes in Argentina was used to facilitate the participant's quantification process [14]. Transformation of frequency of intake and portion size into nutrients (g or $\mathrm{mg} /$ day) was performed using Nutrio software [15]. Physical activity was explored using a validated short form of the International Physical Activity Questionnaire, adapted for Argentina [16] and expressed as number of metabolic equivalent (MET)-min/week. Socio-economic status (SES) was built as a composite indicator following the Argentine Marketing Association's guidelines, which include four domains: educational level, job, housing, and amenities [17].

\section{Statistical analysis}

The descriptive statistical analysis was performed separately for categorical and continuous variables. Categorical variables were analyzed by the Chi-square test. For analytic goals, the following variables were categorized: BMI (normal/underweight: 25.0; overweight: 25.0-29.9; obesity: $\geq 30.0)$, age in years $(<40,40-59, \geq 60)$, SES (low, medium, high), physical activity (PA) (insufficient: 
$<600$ MET-min/week; sufficient: 600-1500 MET-min/ week; high: $>1500$ MET-min/week), and waist circumference (risk of metabolic and cardiovascular diseases: $\geq 94 \mathrm{~cm}$ for men and $\geq 80 \mathrm{~cm}$ for women).

Single foods were clustered into the following 15 groups: milk and yogurt, cheeses, meats and eggs, pulses, non-starchy vegetables, fruits, refined grains and starchy vegetables, whole grains, bakery products, candies (ice cream, chocolates, peanut butter, "dulce de leche"-milk and sugar caramel), added sugar and sweets (sugar, jam, honey), fats (butter, milk cream, vegetable oils and mayonnaise), alcoholic beverages, sugary drinks, and snacks (a small portion of food or drink, especially one eaten between regular meals with high energetic density and sodium).

The results of continuous variables are expressed as means $( \pm \mathrm{SD})$ and categorical variables as percentages. In order to estimate mean intake differences of macronutrients and foods among categories of BMI, one-way analysis of variance was performed and the Bonferroni multiple comparison test was applied. Logistic regression analysis was performed to investigate associations between overweight/obesity and selected socio-demographic, physical activity, and dietary variables. Odds ratios (OR) and the corresponding $95 \%$ confidence intervals $(95 \% \mathrm{CI})$ were estimated.

Macronutrients were categorized as follows: carbohydrate: low $(<45)$, normal $(45-65)$, high $(>65)$ percent of daily total energy intake; proteins: low $(<10)$, normal (10-35), high ( $>35)$ percent of daily total energy intake; total fats: low $(<20)$, normal $(20-35)$, high $(>35)$ percent of daily total energy intake (g) [18]. Daily sodium intake was categorized following the maximum allowed intake of $2.3 \mathrm{~g} /$ day, as suggested by the National Academy of Sciences, Institute of Medicine, Food and Nutrition Board [19]. Single foods were categorized into tertiles following the distribution of the variables among low-/normalweight subjects, without correction for mean energy intake.

Two models were estimated: The first included as the dependent variable overweight versus low-/normal-weight subjects, and the second included obese versus low-/normal-/overweight subjects. For each dependent variable, a model was first fitted without confounders and then a second which included these [Daily Energy Intake (as continuous variable), Gender, Age, SES and PA]. This analytic strategy was first applied to macronutrients as independent variables and then to foods. Food intake was previously categorized as tertiles of the specific food intake among low-/normal-weight subjects.

A $p$ value $<0.05$ was considered as statistically significant. All statistical analyses were performed using Stata 12.1 statistical software [20].

\section{Results}

A total of 4368 out of 4467 sampled subjects (97.7\%) agreed to participate in the study. Data were inconsistent [extreme high $(>7000)$ or low $(<500)$ daily caloric intake] and incomplete (more than $10 \%$ items missing) for 40 and 99 subjects, respectively, so the final sample size was 4328 subjects (58\% males). The cutoff for daily caloric intake seems to be reasonable as there were some obese subjects with daily caloric intake as high as 10,000 calories a day. Moreover, the same cutoff had been applied previously [9].

Sample mean age was $42.69( \pm 17.99)$ years and $51 \%$ of the population was overweight. There was a general tendency to overweight and obesity as age increased. Overweight was present in $24.9,42.0$, and $43.0 \%$ of those $>40$, $40-59$, and 60 or more years old, respectively. Only $8.0 \%$ of subjects under 40 years were obese, but this percentage was $26.5 \%$ among those over 60 .

Results of the descriptive analysis are shown in Table 1. Prevalence of overweight and obesity in this group was 34 and $17 \%$, respectively. Sixty percent of men and $45 \%$ of women were overweight. There was a negative association between SES and BMI $(p<0.01)$ : the higher the SES, the lower the prevalence of overweight.

Physical activity level was insufficient in $68 \%(<600$ MET$\mathrm{min} /$ week) of the sample. Sixty-eight percent of overweight and $82 \%$ of obese subjects did not reach a sufficient level of physical activity. Waist circumference showed that $47 \%$ of the subjects were at risk of metabolic and cardiovascular diseases, including $77 \%$ of overweight/obese people.

Table 2 summarizes the information regarding dietary exposure. Mean energy intake was $2853 \mathrm{kcal}$ daily. There were statistically significant differences among BMI categories for mean intake of calcium, milk and yogurt, meats and eggs, pulses, refined grains and starchy vegetables, and candies. The multiple comparison provided by the Bonferroni test showed statistically significant differences among BMI categories for mean intake of carbohydrate, fiber and bakery products. There were no statistically significant differences in the mean intake of different food groups between genders and among SES categories (data not shown). There was a statistically significant difference between gender in alcoholic and non-alcoholic beverage intake $(p<0.01)$.

\section{Risk analysis}

\section{Nutrients}

Model: Overweight versus normal There were lower ORs for normal (OR 0.6, $95 \%$ CI 0.5-0.7) and high (OR 0.7, $95 \%$ CI $0.5-0.9)$ tertiles of carbohydrate and for calcium intake (OR 0.9, $95 \%$ CI 0.98-0.99) but only the effects for 
Table 1 Socio-demographic and anthropometric characteristics in relation to body mass index of the subjects studied $(n=4328)$

\begin{tabular}{|c|c|c|c|c|c|c|c|}
\hline & \multicolumn{7}{|c|}{ Body Mass Index } \\
\hline & \multirow{2}{*}{\multicolumn{2}{|c|}{$\begin{array}{l}\text { Normal/under- } \\
\text { weight }\end{array}$}} & \multirow{2}{*}{\multicolumn{2}{|c|}{$\begin{array}{l}\text { Overweight } \\
\text { BMI 25-29.9 }\end{array}$}} & \multirow{2}{*}{\multicolumn{2}{|c|}{$\begin{array}{l}\text { Obesity } \\
\mathrm{BMI} \geq 30\end{array}$}} & \multirow[t]{3}{*}{$\begin{array}{l}\text { Total } \\
n\end{array}$} \\
\hline & & & & & & & \\
\hline & $n$ & $\%$ & $n$ & $\%$ & $n$ & $\%$ & \\
\hline \multicolumn{8}{|l|}{ Age (years)* } \\
\hline$<40$ & 1391 & $65.61 *$ & 519 & $24.99 *$ & 167 & $8.04 *$ & 2077 \\
\hline $40-59$ & 450 & $33.78 *$ & 560 & $42.04 *$ & 322 & $24.17 *$ & 1332 \\
\hline$\geq 60$ & 279 & $30.36^{*}$ & 396 & $43.09 *$ & 244 & $26.55^{*}$ & 919 \\
\hline \multicolumn{8}{|l|}{ Gender* } \\
\hline Male & 745 & $40.67^{\#}$ & 781 & 42.63 & 306 & $16.70^{\#}$ & 1832 \\
\hline Female & 1375 & $55.09 *$ & 694 & $27.80 *$ & 427 & $17.11^{*}$ & 2496 \\
\hline \multicolumn{8}{|l|}{ SES* } \\
\hline Low & 941 & $42.79 *$ & 779 & $35.43 *$ & 479 & $21.78 *$ & 2199 \\
\hline Medium & 788 & $52.67 *$ & 509 & $34.02 *$ & 199 & $13.30 *$ & 1496 \\
\hline High & 391 & $61.77 *$ & 187 & $29.54 *$ & 55 & $8.69 *$ & 633 \\
\hline \multicolumn{8}{|l|}{ Physical activity* } \\
\hline Insufficient (<600 MET-min/week) & 1314 & $44.94 *$ & 1011 & $34.58 *$ & 599 & $20.49 *$ & 2924 \\
\hline Sufficient (600-1500 MET-min/week) & 476 & $55.87 *$ & 288 & $33.80 *$ & 88 & $10.33 *$ & 852 \\
\hline High (>1500 MET-min/week) & 330 & $59.78 *$ & 176 & $31.88 *$ & 46 & $8.33 *$ & 552 \\
\hline \multicolumn{8}{|l|}{ Waist circumference* } \\
\hline Without risk & 1749 & 77.01 & 503 & 22.15 & 19 & 0.84 & 2271 \\
\hline With risk & 371 & 18.04 & 972 & 47.25 & 714 & 34.71 & 2057 \\
\hline Total & 2120 & 48.98 & 1475 & 34.08 & 733 & 16.94 & 4328 \\
\hline
\end{tabular}

Córdoba Obesity and Diet Study (CODIES), Argentina 2012

* Obesity versus overweight versus normal/underweight: $p<0.05$

\# Obesity versus normal/underweight: $p<0.05$ normal carbohydrate and for calcium remained when the estimates were adjusted for the set of confounders (Table 3).

Model: Obesity versus normal/overweight There were lower ORs for the high (OR 0.4, $95 \%$ CI 0.3-0.6) and normal (OR 0.6, $95 \%$ CI 0.4-0.9) intake of fats and for normal intake of carbohydrate (OR 0.7, $95 \%$ CI 0.5-0.9) in the unadjusted model, but only the effects for high intake of fats and normal intake of carbohydrate remained statistically significant in the adjusted model $(p<0.05)$. There was also a positive effect for sodium intake (OR 1.5, $95 \%$ CI 1.1-1.8) in the adjusted model (Table 3).

\section{Foods}

Model: Overweight versus normal There were lower ORs for the second and third tertiles of candies (OR 0.7, $95 \%$ CI $0.6-0.9$; OR $0.5,95 \%$ CI $0.5-0.7$, respectively) and milk and yogurt (OR 0.71, $95 \%$ CI 0.7-0.9; OR 0.7, $95 \%$ CI 0.6-0.8, respectively) in the unadjusted model. These effects remained only in the third tertile of candies, milk, and yogurt in the adjusted model, but the second tertiles trend test was statistically significant $(p<0.05$, Table 4).

In the adjusted model, the higher ORs were for third tertiles of sugar and sweets (OR 0.8, $95 \%$ CI 0.6-0.9) and Sugary Drinks (OR 1.2, $95 \%$ CI 1.03-1.5, trend $p<0.05$ ); nevertheless, the second tertiles trend test of these foods was statistically significant $(p<0.05$, Table 4$)$.

Model: Obesity versus normal/overweight There were higher ORs for both tertiles of refined grains and starchy vegetables (OR 1.7, 95 \% CI 1.2-2.3; OR 2.4, $95 \%$ CI 1.63.8 ) and the third tertile of snacks (OR 1.4, $95 \%$ CI 1.11.8 ), and lower ORs for the third tertile of alcoholic beverages (OR 0.7, $95 \%$ CI 0.5-0.9) and both tertiles of sugar and sweets (OR 0.6, $95 \%$ CI 0.4-0.7; OR 0.7, $95 \% \mathrm{CI}$ $0.5-0.8$ ), candies (OR 0.7, $95 \%$ CI $0.6-0.9$; OR $0.7,95 \%$ CI 0.5-0.9), milk and yogurt (OR 0.8, $95 \%$ CI 0.6-0.9; OR $0.6,95 \%$ CI $0.5-0.8$ ) and pulses (OR 0.7, $95 \%$ CI 0.6-0.9; OR $0.8,95 \%$ CI 0.6-0.9) in the adjusted model, all with statistically significant trends. 
Table 2 Energy, macronutrients, and food intakes by body mass index of subjects studied $(n=4328)$

\begin{tabular}{|c|c|c|c|c|c|c|c|c|}
\hline & \multicolumn{8}{|c|}{ Body Mass Index } \\
\hline & \multirow{2}{*}{\multicolumn{2}{|c|}{$\frac{\text { Normal/underweight }}{\mathrm{BMI}<25}$}} & \multirow{2}{*}{\multicolumn{2}{|c|}{$\frac{\text { Overweight }}{\text { BMI 25-29.9 }}$}} & \multirow{2}{*}{\multicolumn{2}{|c|}{$\frac{\text { Obesity }}{\text { BMI } \geq 30}$}} & \multirow{2}{*}{\multicolumn{2}{|c|}{ Total }} \\
\hline & & & & & & & & \\
\hline & Mean & SD & Mean & SD & Mean & SD & Mean & SD \\
\hline Energy intake (kcal) & 2800 & 1.1 & 2800 & 1.0 & 2800 & 1.1 & 2800 & 1.1 \\
\hline Carbohydrate (g) & 391.0 & 209.3 & 379.5 & 183.2 & 398.9 & 206.7 & 388.4 & 200.4 \\
\hline Protein (g) & 107.7 & 45.2 & 108.5 & 45.8 & 110.0 & 47.0 & 108.4 & 45.7 \\
\hline Total fats (g) & 101.6 & 41.6 & 102.0 & 50.1 & 99.1 & 43.8 & 101.3 & 45.1 \\
\hline Fiber (g) & 19.5 & 9.9 & 20.1 & 10.2 & 20.3 & 11.01 & 19.8 & 10.2 \\
\hline Sodium (g) & 2039.3 & 1175.6 & 1990.2 & 1.1 & 2.1 & 1.1 & 2.0 & 1.1 \\
\hline Calcium $(\mathrm{mg})^{*}$ & 852.8 & 496.7 & 804.4 & 484.0 & 818.1 & 486.1 & 830.4 & 491.0 \\
\hline Milk and yogurt (g) & $209.1^{*, \#}$ & 221.1 & $188.9^{*}$ & 224.2 & $169.6^{\#}$ & 197.7 & 195.6 & 218.8 \\
\hline Cheeses (g) & 31.3 & 36.7 & 30.2 & 35.6 & 32.1 & 49.97 & 31.1 & 38.9 \\
\hline Meats and eggs (g) & $189.3^{*, \#}$ & 109.0 & $199.9^{*}$ & 110.3 & $206.2^{\#}$ & 121.1 & 195.8 & 111.7 \\
\hline Pulses $(\mathrm{g})$ & $9.2^{*, \#}$ & 20.8 & $6.9^{*}$ & 14.6 & $6.6^{\#}$ & 12.9 & 8.0 & 17.7 \\
\hline Non-starchy vegetables (g) & 259.2 & 165.2 & 263.0 & 163.5 & 270.8 & 171.16 & 262.5 & 165.7 \\
\hline Fruits $(\mathrm{g})$ & 249.6 & 215.6 & 261.6 & 275.8 & 268.3 & 230.98 & 256.8 & 240.3 \\
\hline Refined grains and starchy vegetables $(\mathrm{g})^{*}$ & $266.7^{\#}$ & 177.1 & 279.2 & 181.9 & $287.4^{\#}$ & 205.83 & 274.5 & 184.0 \\
\hline Whole grains $(\mathrm{g})$ & 24.1 & 50.2 & 25.4 & 56.7 & 24.1 & 56.91 & 24.6 & 53.6 \\
\hline Bakery products $(\mathrm{g})$ & 65.1 & 78.6 & 60.1 & 74.1 & 66.2 & 78.32 & 63.6 & 77.1 \\
\hline Candies $(g)^{*}$ & $26.4^{*, \#}$ & 33.4 & $19.7 *$ & 26.7 & $18.4^{\#}$ & 25.97 & 22.8 & 30.3 \\
\hline Added sugar and sweets (g) & 29.2 & 31.9 & 30.4 & 34.1 & 28.5 & 32.39 & 29.5 & 32.7 \\
\hline Fats $(\mathrm{g})$ & 48.6 & 34.1 & 47.7 & 30.6 & 47.9 & 35.91 & 48.2 & 33.2 \\
\hline Alcoholic beverages (cc) & 102.9 & 201.6 & 111.2 & 192.2 & 95.9 & 195.21 & 104.5 & 197.4 \\
\hline Non-alcoholic caloric beverages (cc) & 454.6 & 609.6 & 460.4 & 591.5 & 419.1 & 606.8 & 450.6 & 603.1 \\
\hline Snacks (g) & 1.4 & 6.7 & 1.2 & 6.1 & 1.4 & 4.6 & 1.3 & 6.2 \\
\hline
\end{tabular}

Córdoba Obesity and Diet Study (CODIES), Argentina 2012

* Overweight versus normal/underweight: $p<0.05$

\# Obesity versus normal/underweight: $p<0.05$ (analysis of variance)

\section{Discussion}

This is the first study of eating habits in urban populations of Argentina and their association with the current prevalence of overweight and obesity. Some demographic characteristics associated with categories of BMI had been identified in the same population [9].

In this study, the prevalence of obesity was $17 \%$ and of overweight $51 \%$. Overweight (overweight vs normal) was negatively associated with fats, calcium, sugar, and sweets, candies and milk, and yogurt intakes and positively associated with sugary drinks. Obesity (obesity vs normal/overweight) was found to be negatively associated with fats, carbohydrates, sugar and sweets, alcoholic beverages, milk and yogurt, and pulses intakes and positively associated with sodium, refined grains and starchy vegetables, and snacks intakes.
Overall, $60 \%$ of men and $45 \%$ of women were overweight, while obesity was $17 \%$. There was, however, a significant difference between genders, with a higher prevalence of women among obese subjects. Previous studies about overweight and obesity prevalence in Argentina have been conducted. Although the methodological approach was different, higher rates of overweight (about $55 \%$ ) and obesity $(26 \%)$ were found $[21,22]$ in two small cities. The 2007 National Survey of Health and Nutrition found a prevalence of overweight in women aged 19-49 years of $44.3 \%$ (24.9\% overweight and $19.4 \%$ obese) [23], and in the first and second National Survey of Risk Factors (2005 and 2009), more than half the population $(53.4 \%)$ had overweight [24]. In our study, while overweight women had a prevalence similar to that reported nationally, the distribution of overweight and obesity was different: 28 and $17 \%$, respectively. 
Table 3 Overweight and obesity: unadjusted and adjusted ORs and $95 \% \mathrm{CI}$ of nutritional variables estimated from logistic regression models (LRM)

\begin{tabular}{|c|c|c|c|c|c|c|c|c|c|}
\hline \multirow[t]{3}{*}{ Variable } & \multirow[t]{3}{*}{ Category } & \multicolumn{4}{|c|}{ Overweight versus normal $(n=3582)$} & \multicolumn{4}{|c|}{$\begin{array}{l}\text { Obesity versus normal/over- } \\
\text { weight }(n=4328)\end{array}$} \\
\hline & & \multicolumn{2}{|c|}{ Unadjusted model } & \multicolumn{2}{|c|}{ Adjusted model $^{\mathrm{a}}$} & \multicolumn{2}{|c|}{$\begin{array}{l}\text { Unadjusted } \\
\text { model }\end{array}$} & \multicolumn{2}{|c|}{$\begin{array}{l}\text { Adjusted } \\
\text { model }^{\mathrm{a}}\end{array}$} \\
\hline & & OR & $95 \% \mathrm{CI}$ & OR & $95 \% \mathrm{CI}$ & OR & $95 \%$ CI & OR & $95 \% \mathrm{CI}$ \\
\hline \multirow[t]{3}{*}{ Carbohydrate } & Low & $1^{ \pm}$ & - & 1 & - & 1 & - & 1 & - \\
\hline & Normal & 0.6 & {$[0.5,0.7]$} & 0.6 & {$[0.5,0.8]$} & 0.7 & {$[0.5,0.9]$} & 0.7 & {$[0.6,0.9]$} \\
\hline & High & 0.7 & {$[0.5,0.9]$} & 0.9 & {$[0.7,1.4]$} & 0.8 & {$[0.6,1.1]$} & 0.9 & {$[0.6,1.3]$} \\
\hline \multirow[t]{3}{*}{ Protein } & Low & 1 & - & 1 & - & $1^{ \pm}$ & - & 1 & - \\
\hline & Normal & 0.9 & {$[0.6,13]$} & 0.9 & {$[0.5,1.3]$} & 0.7 & {$[0.4,1.03]$} & 0.7 & {$[0.5,1.1]$} \\
\hline & High & 1.3 & {$[0.2,9]$} & 1.4 & {$[0.1,12.1]$} & 1.9 & {$[0.3,11.1]$} & 1.8 & {$[0.2,12.3]$} \\
\hline \multirow[t]{3}{*}{ Fats } & Low & $1^{ \pm}$ & - & 1 & - & $1^{ \pm}$ & - & $1^{ \pm}$ & - \\
\hline & Normal & 0.9 & {$[0.6,1.2]$} & 1.2 & {$[0.8,1.8]$} & 0.6 & {$[0.4,0.9]$} & 0.7 & {$[0.5,1.1]$} \\
\hline & High & 0.7 & {$[0.5,1]$} & 1.1 & {$[0.7,1.7]$} & 0.4 & {$[0.3,0.6]$} & 0.6 & {$[0.4,0.9]$} \\
\hline \multirow[t]{3}{*}{ Fiber } & Low & $1^{ \pm}$ & - & 1 & - & 1 & - & 1 & - \\
\hline & Normal & 1.1 & {$[0.9,1.4]$} & 1.1 & {$[0.7,1.2]$} & 1.1 & {$[0.8,1.4]$} & 1.1 & {$[0.8,1.4]$} \\
\hline & High & 1.4 & {$[1.1,1.7]$} & 1.2 & {$[0.9,1.5]$} & 1.1 & {$[0.9,1.5]$} & 1.1 & {$[0.8,1.3]$} \\
\hline Calcium $^{\#}$ & & $0.9^{ \pm}$ & {$[0.98,0.99]$} & $0.9^{ \pm}$ & {$[0.98,0.99]$} & 1.0 & {$[0.9,1.0]$} & 1.0 & {$[0.9,1.0]$} \\
\hline \multirow[t]{2}{*}{ Sodium ${ }^{\&}$} & $\leq$ Upper intake & 1 & - & 1 & & 1 & - & $1^{ \pm}$ & - \\
\hline & $>$ Upper intake & 0.9 & {$[0.8,1.1]$} & 0.9 & {$[0.7,1.1]$} & 1.1 & {$[0.9,1.3]$} & 1.5 & {$[1.1,1.8]$} \\
\hline \multicolumn{10}{|c|}{ CODIES, Argentina 2012} \\
\hline \multicolumn{10}{|c|}{${ }^{ \pm} p$ value for trend $<0.05$} \\
\hline \multicolumn{10}{|c|}{ a Gender, age, energy intake, SES, status, physical activity adjusted OR } \\
\hline \multicolumn{10}{|c|}{ \# Continuous variable } \\
\hline \& Maximum A & llowed Intake $\leftrightharpoons$ & & ily) & & & & & & \\
\hline
\end{tabular}

Worldwide, as mean BMI has increased, there has been an increasing tendency to obesity [8]. Overweight and obesity prevalence in Córdoba was lower than in the USA (33.8 and $68 \%$, respectively) but higher than in European countries [25]. In Latin America, there is a data conflict, as some studies have identified Argentina as having an overweight prevalence of less than $50 \%$ [26] while others have reported that more than $15 \%$ of Argentineans are obese as is the case in Colombia, Paraguay, and Uruguay [27].

The two keys for controlling or reducing weight are diet and exercise. A sedentary lifestyle is the main cause of weight gain $[28,29]$. As in other South American populations [30], $67 \%$ of the individuals in this study did not engage in sufficient physical activity even though the WHO reports that a sedentary lifestyle is the fourth attributable risk factor for death [7]. The protective effect of a high or sufficient level of physical activity was already shown in this population [9], and the results of this study agree with cross-sectional and prospective studies, which have highlighted the strength of the association of low levels of physical activity with obesity [31-33].

\section{Macronutrients}

In this population, the features mentioned above, coupled to excessive caloric intake, resulted in weight gain. Male and female median energy intakes were higher than the reference values [18]. Excessive caloric intake has been related with overweight and obesity in some cases [34, 35], but in others, this association has been found only with overweight [36]. It is worth noting that underreporting of dietary intake of obese people could cause the lack of association between intake and obesity, as has been documented [37, 38].

Even though diet is accepted as a determinant factor of overweight and obesity, the role of certain nutrients, especially fats $[39,40]$, is controversial, partly due to the impossibility of detecting low effects of nutrients, such as their biological interactions with other metabolic factors, which makes the measurement of individual effects difficult [41]. Carbohydrates can cause high-energy intake and later weight increase [42]. In this study, the average percentage of energy provided by carbohydrates was $53.08 \%$, similar to that reported for the southeastern US population 
Table 4 Logistic regression: OR and $95 \%$ CI for foods

\begin{tabular}{|c|c|c|c|c|c|c|c|c|c|}
\hline \multirow[t]{3}{*}{ Variable } & \multirow[t]{3}{*}{$\begin{array}{l}\text { Tertiles } \\
\text { Reference 1st tertile }\end{array}$} & \multicolumn{4}{|c|}{ Overweight versus normal ( $n=3582)$} & \multicolumn{4}{|c|}{$\begin{array}{l}\text { Obesity versus normal/overweight } \\
(n=4328)\end{array}$} \\
\hline & & \multicolumn{2}{|c|}{ Unadjusted model } & \multicolumn{2}{|c|}{ Adjusted model $^{\mathrm{a}}$} & \multicolumn{2}{|c|}{ Unadjusted model } & \multicolumn{2}{|c|}{ Adjusted model $^{\mathrm{a}}$} \\
\hline & & OR & $95 \% \mathrm{CI}$ & OR & $95 \% \mathrm{CI}$ & OR & $95 \% \mathrm{CI}$ & OR & $95 \% \mathrm{CI}$ \\
\hline \multirow[t]{2}{*}{ Meats and eggs } & 2nd & 1.1 & {$[0.9,1.3]$} & 1.1 & {$[0.9,1.3]$} & 0.7 & {$[0.5,0.9]$} & 0.7 & {$[0.5,0.9]$} \\
\hline & $3 \mathrm{rd}$ & 1.05 & {$[0.7,1.4]$} & 1.07 & {$[0.7,1.5]$} & 0.7 & {$[0.5,1.1]$} & 0.7 & {$[0.5,1.1]$} \\
\hline \multirow[t]{2}{*}{ Whole grains } & 2nd & 1.01 & {$[0.8,1.3]$} & 1.08 & {$[0.8,1.4]$} & 0.9 & {$[0.7,1.2]$} & 0.9 & {$[0.6,1.2]$} \\
\hline & $3 \mathrm{rd}$ & 1.04 & {$[0.9,1.2]$} & 1.08 & {$[0.9,1.3]$} & 0.8 & {$[0.7,1.04]$} & 0.9 & {$[0.7,1.1]$} \\
\hline \multirow[t]{2}{*}{ Fruits } & 2 nd & 1.03 & {$[0.8,1.2]$} & 1.01 & {$[0.8,1.2]$} & 1.1 & {$[0.9,1.3]$} & 1.05 & {$[0.8,1.3]$} \\
\hline & $3 \mathrm{rd}$ & 1.1 & {$[0.9,1.3]$} & 1.1 & {$[0.9,1.3]$} & 1.2 & {$[1.03,1.6]$} & 1.2 & {$[0.9,1.5]$} \\
\hline \multirow[t]{2}{*}{ Refined grains and starchy vegetables } & 2nd & 1.3 & {$[1.04,1.7]$} & 1.2 & {$[0.9,1.6]$} & 1.6 & {$[1.2,2.2]$} & $1.7^{ \pm}$ & {$[1.2,2.3]$} \\
\hline & $3 \mathrm{rd}$ & 1.4 & {$[0.9,1.9]$} & 1.4 & {$[0.9,2.0]$} & 2.1 & {$[1.4,3.3]$} & 2.4 & {$[1.6,3.8]$} \\
\hline \multirow[t]{2}{*}{ Sugar and sweets } & 2 nd & 0.9 & {$[0.7,1.1]$} & $0.7^{ \pm}$ & {$[0.6,0.9]$} & 0.6 & {$[0.5,0.8]$} & $0.6^{ \pm}$ & {$[0.4,0.7]$} \\
\hline & $3 \mathrm{rd}$ & 0.9 & {$[0.8,1.1]$} & 0.8 & {$[0.6,0.9]$} & 0.8 & {$[0.7,1.05]$} & 0.7 & {$[0.5,0.8]$} \\
\hline \multirow[t]{2}{*}{ Bakery products } & 2nd & 0.9 & {$[0.8,1.2]$} & 1.09 & {$[0.9,1.3]$} & 0.9 & {$[0.8,1.2]$} & 1.01 & {$[0.8,1.2]$} \\
\hline & $3 \mathrm{rd}$ & 0.9 & {$[0.7,1.1]$} & 1.1 & {$[0.9,1.4]$} & 1.1 & {$[0.9,1.4]$} & 1.2 & {$[0.9,1.5]$} \\
\hline \multirow[t]{2}{*}{ Candies } & $2 \mathrm{nd}$ & 0.7 & {$[0.6,0.9]$} & $0.8^{ \pm}$ & {$[0.7,1.0]$} & 0.7 & {$[0.6,0.9]$} & $0.7^{ \pm}$ & {$[0.6,0.9]$} \\
\hline & $3 \mathrm{rd}$ & 0.5 & {$[0.5,0.7]$} & 0.7 & {$[0.5,0.8]$} & 0.6 & {$[0.5,0.8]$} & 0.7 & {$[0.5,0.9]$} \\
\hline \multirow[t]{2}{*}{ Fats } & $2 \mathrm{nd}$ & 1.01 & {$[0.8,1.2]$} & 0.9 & {$[0.8,1.1]$} & 0.9 & {$[0.8,1.2]$} & 0.9 & {$[0.7,1.1]$} \\
\hline & $3 \mathrm{rd}$ & 1.06 & {$[0.9,1.3]$} & 1.2 & {$[0.9,1.4]$} & 0.8 & {$[0.6,1.0]$} & 0.8 & {$[0.6,1.05]$} \\
\hline \multirow[t]{2}{*}{ Alcoholic beverages } & 2nd & 0.8 & {$[0.7,1.02]$} & 0.8 & {$[0.7,1.05]$} & 0.7 & {$[0.6,0.9]$} & $0.9^{ \pm}$ & {$[0.7,1.08]$} \\
\hline & $3 \mathrm{rd}$ & 1.03 & {$[0.8,1.2]$} & 0.9 & {$[0.7,1.3]$} & 0.6 & {$[0.5,0.8]$} & 0.7 & {$[0.5,0.9]$} \\
\hline \multirow[t]{2}{*}{ Sugary drinks } & $2 \mathrm{nd}$ & 0.9 & {$[0.8,1.13]$} & $1.1^{ \pm}$ & {$[0.9,1.3]$} & 0.9 & {$[0.7,1.1]$} & 1.01 & {$[0.8,1.2]$} \\
\hline & $3 \mathrm{rd}$ & 1.06 & {$[0.9,1.3]$} & 1.2 & {$[1.03,1.5]$} & 0.8 & {$[0.7,1.05]$} & 0.9 & {$[0.7,1.2]$} \\
\hline \multirow[t]{2}{*}{ Non starchy vegetables } & 2nd & 1.08 & {$[0.9,1.3]$} & 1.01 & {$[0.8,1.2]$} & 1.1 & {$[0.9,1.4]$} & 1.1 & {$[0.8,1.3]$} \\
\hline & $3 \mathrm{rd}$ & 1.04 & {$[0.8,1.2]$} & 1.0 & {$[0.8,1.2]$} & 1.2 & {$[1.0,1.5]$} & 1.1 & {$[0.9,1.4]$} \\
\hline \multirow[t]{2}{*}{ Milk and yogurt } & 2 nd & 0.71 & {$[0.7,0.9]$} & $0.8^{ \pm}$ & {$[0.7,1.02]$} & 0.7 & {$[0.6,0.8]$} & $0.8^{ \pm}$ & {$[0.6,0.9]$} \\
\hline & $3 \mathrm{rd}$ & 0.7 & {$[0.6,0.8]$} & 0.7 & {$[0.6,0.9]$} & 0.6 & {$[0.5,08]$} & 0.6 & {$[0.5,0.8]$} \\
\hline \multirow[t]{2}{*}{ Cheeses } & 2nd & 0.9 & {$[0.8,1.1]$} & 0.9 & {$[0.8,1.1]$} & 0.9 & {$[0.8,1.2]$} & 0.9 & {$[0.7,1.2]$} \\
\hline & $3 \mathrm{rd}$ & 0.9 & {$[0.7,1.1]$} & 0.9 & {$[0.7,1.1]$} & 1.1 & {$[0.9,1.4]$} & 1.1 & {$[0.8,1.4]$} \\
\hline Snacks & $3 \mathrm{rd}$ & 0.8 & {$[0.7,1.02]$} & 1.05 & {$[0.8,1.2]$} & 1.2 & {$[1.1,1.5]$} & $1.4^{ \pm}$ & {$[1.1,1.8]$} \\
\hline \multirow[t]{2}{*}{ Pulses } & 2nd & 1.1 & {$[0.9,1.3]$} & 1.07 & {$[0.9,1.3]$} & 0.7 & {$[0.6,0.8]$} & $0.7^{ \pm}$ & {$[0.6,0.9]$} \\
\hline & $3 r d$ & 0.8 & {$[0.7,1.1]$} & 1.03 & {$[0.8,1.2]$} & 0.7 & {$[0.6,0.9]$} & 0.8 & {$[0.6,0.9]$} \\
\hline
\end{tabular}

CODIES, Argentina 2012

There are no subjects in tertile 2 for snacks

${ }^{ \pm} p$ value for trend $<0.05$

${ }^{a}$ Gender, age, energy intake, SES, status, physical activity adjusted OR

[43]. The high intake of lipids in Argentinean diet is probably due to consumption of meat and poultry (27 and $8.6 \mathrm{~g} /$ person/day respectively), the lipid content of which (23.6/100 g from meat, 8.7/100 g from poultry) [44] provides half the recommended daily intake of this nutrient. This pattern has been described in other studies conducted in Córdoba [45]. This increased consumption of animal protein has been associated with higher risk of obesity [43], but this has not been evidenced in our study. It is worth noting that meat and dairy products come from a mix of feedlot and pastoral system animals [46].
Great attention has been paid in recent years to the effect of dietary calcium on weight and body composition. Over the past decade, some studies have suggested an effect of calcium on energy and lipid balance, highlighting the importance of an adequate intake of dairy products [47]. Although in this study, calcium intake was associated only with overweight, there was a negative association between milk and yogurt intake not only with overweight but also with obesity. Other components of dairy products are probably important in the energy balance. These include certain peptides with inhibitory action on the 
angiotensin-converting enzyme [48], conjugated linoleic acid [49], and branched-chain amino acids [50]. Other studies have investigated the amount of dairy intake in relation to the development of obesity and found that the relative risk of developing obesity was reduced by $18 \%$ for each unit of increase in the amount of dairy products consumed [51].

A higher intake of fats and alcohol may contribute to the development of obesity, but this has not been evidenced in our study. However, higher intake of fat meats and alcohol is very common in Cordoba city $[10,11]$. There is evidence that current and lifetime consumption of alcohol is positively associated with general and central obesity in both genders, regardless of the social and behavioral characteristics [52]. In our study, all individuals, regardless of their nutritional status, drank an average of $100 \mathrm{cc} /$ day of alcoholic beverages, with significant differences between genders. Moreover, a negative association was found when ingesting less than $100 \mathrm{cc} /$ day.

\section{Foods}

The beneficial effect of the inclusion of fiber in the diet is well known, as it can reduce energy intake and help prevent or treat obesity. Probably the fiber content of foods, together with their content of lipids and proteins, can directly influence overweight and obesity by its contribution to the glycemic index (GI). In effect, some studies have indicated that eating low-GI foods resulted in a $0.5 \mathrm{~kg}$ reduction in body fat compared with individuals who ingest high-GI foods [53]. In the present study, the mean intake was $20 \mathrm{~g} /$ day and $50 \%$ of subjects consumed less than $18 \mathrm{~g} /$ day of fiber, which increased to $22 \mathrm{~g} /$ day in high SES. That consumption is less than the recommended intake of fiber for Argentina's population (25-30 g/day) [54]. International studies reveal differences in consumption by gender. Chilean women who consumed more fiber presented a positive health effect [55], but this effect was not found in our study, probably due to the similarly low consumption of fiber among all study subjects.

Evidence suggests the potential beneficial effects of the slowly digestible and resistant fiber contained in whole grains, pulses, and vegetables [56]. Their intake in the Córdoba population was very low, particularly the consumption of pulses, which was less than $10 \mathrm{~g} /$ day, and even less at $6 \mathrm{~g}$ /day in subjects with obesity. In contrast, the mean intake of refined grains and starchy vegetables was greater than $260 \mathrm{~g} / \mathrm{day}$ and among people with obesity was close to $300 \mathrm{~g} / \mathrm{day}$. The intake of whole grains was not more than $25 \mathrm{~g} /$ day. The reduced risk of chronic diseases among persons who consumed pulses and whole grains is probably related to the low GI. Low-GI foods cause a lower concentration of circulating insulin due to decreased postprandial glucose response [56]. The low insulin secretion steadily reduces the levels of free fatty acids, improves cellular metabolism of glucose [55], keeps blood glucose levels nearer the lower limit despite continuous glucose absorption from the intestine, and avoids the lipogenic effect caused by high-GI foods [42].

A negative correlation between the consumption of fruit and non-starchy vegetables and BMI in adults has been reported [30, 57]. A US study in adults found that people with a high consumption of fruits and non-starchy vegetables had a lower prevalence of obesity [58]. In this study, consumption of fruits and non-starchy vegetables was very low and similar to that observed in other studies $[8,59-61]$. This is probably due to the fact that a large part of the population of Córdoba City has a low income and less access to food such as fruits and non-starchy vegetables, leading to a lower intake of vitamins, minerals, fiber, and water.

It has been shown that sugary drinks do not produce satiety in a similar way to that of solid foods with an equivalent content of carbohydrates [62]. An increased consumption of sugary drinks has been found to be associated with weight gain [63, 64], as was found in our study. The high content of fructose in these beverages may play a role in this mechanism. The amount of fructose in fruits is relatively small compared with that in sugary drinks [65], Sugary drinks have added corn syrups, which contain higher concentrations of fructose. Fructose has been implicated as a possible independent risk factor for the development of obesity [66] and has been linked to central adiposity and hyperlipidemia [67].

Studies on obesity and the influence of dietary factors have established that snack consumption is positively associated with overweight and obesity [36]. Moreover, other studies have reported that among middle-aged men, the frequency of snack consumption was positively and significantly related to insulin resistance [68]. Snacks are highenergy foods and the different preservatives that they contain potentiate the effects of other components [69]. The choice of these foods and the consumption of bakery products, sugar, and sweets should also be considered from an anthropological point of view [56]. Generally, when individuals select these foods, sensory perceptions and pleasure are priorities [70]. Some studies suggest that intensely pleasurable emotions associated with food are coupled to neurological system activity on the basis of reward/motivation, emotional (limbic), and warning processes [71]. Other clinical studies suggest that the most desired foods are those containing fat, sugar, or both [72]. There is thus a connection between the consumption patterns of snacks, the increase in the energy density of foods consumed and altered satiety, which together may play a role in obesity. 


\section{Methodological considerations}

Some methodological issues need to be considered. This study was based on a population-based random sample of 4328 subjects which constitutes its principal strength. The sample is well suited to estimate with precision and validity the true prevalence of the two conditions. Underreporting of diet intake is an issue of overweight/obese people. However, if this bias is present in our study, this constitutes a non-differential misclassification of the exposure and the estimates should be biased toward the null [73]. Furthermore, the scenario where this study was conducted should be considered. The particular dietary pattern may put the Argentinean population in the upper tail of dietary exposure to proteins and fats and in the lower tail of non-starchy vegetables and pulses. Finally, this cross-sectional study does not permit causal inferences to be drawn but only finds associations.

\section{Conclusions}

Overweight and obesity are a public health threat in this population. A higher intake of sugar, fat and sodium and a lower consumption of vegetables, fruits, and whole grains characterize the dietary pattern of this population. Further studies are needed to better understand the mechanisms underlying this pattern and the high prevalence of overweight and obesity. Obesity management must take into account all these factors in planning programs of health promotion and the prevention of obesity and its complications.

Acknowledgments This research was partially supported by the National Science and Technology Agency (FONCyT) grants PICT 2008-1814 and PICT-O 2005-36035, and the Science and Technology Secretary of the University of Córdoba (SECyT-UNC) Grant 05/ H207. Ana De La Quintana's research was supported by fellowship provided by SECyT-UNC. The authors also would like to acknowledge the collaboration of all the participants in the sample.

Conflict of interest The authors declare that they have no conflicts of interest.

\section{References}

1. De Girolami DH (1999) Definición y medios diagnóstico. In: Braguinsky J (ed) Obesidad, 2nd edn. El Ateneo, Bs As, pp 15-39

2. Martí A, Razquin C, Martíne JA (2006) Papel de las interacciones genes-nutrientes en el desarrollo de obesidad. Rev Esp Obes 4:86-96

3. Drewnowski A (2000) Nutrition transition and global dietary trends. Nutrition 16:486-487

4. Pan American Health Organization. Obesity and poverty: a new public health challenge (Scientific Publication No. 576) Washington, D.C. PAHO, pp 124
5. Popkin BM, Gordon-Larsen P (2004) The nutrition transition: worldwide obesity dynamics and their determinants. Int J Obes Relat Metab Disord 28:S2-S9

6. Hill JO, Wyatt HR, Reed GW, Peters JC (2003) Obesity and the environment: Where do we go from here? Science 299:853-855

7. World Health Organization (2009) Global health risks: mortality and burden of disease attributable to selected major risks. http:// who.int/healthinfo/global_burden_disease/GlobalHealthRisks_ report_full.pdf. Accessed 26 June 2013

8. Finucane MM, Stevens GA, Cowan MJ et al (2011) National, regional, and global trends in body-mass index since 1980: systematic analysis of health examination surveys and epidemiological studies with 960 country-years and 9.1 million participants. Lancet 377:557-567. doi:10.1016/s0140-6736(10)62037-5

9. Aballay LR, Osella AR, Celi A, Diaz MP (2009) Overweight and obesity: prevalence and their association with some social characteristics in a random sample population-based study in Cordoba city, Argentina. Obes Res Clin Pract 3:75-83. doi:10.1016/j.orcp.2009.01.001

10. Pou SA, Díaz MD, Osella AR (2012) Applying multilevel model to the relationship of dietary patterns and colorectal cancer: an ongoing case-control study in Córdoba, Argentina. Eur J Nutr 51:755-764. doi:10.1007/s00394-011-0255-7

11. Pou SA, Niclis C, Aballay LR, Tumas N, Román MD, Becaría Coquet J, Muñoz SE, Diaz MP (2014) Cáncer y su asociación con patrones alimentarios en Córdoba, Argentina. Nutr Hosp 29:618-628

12. Filozof C, Gonzalez C, Sereday M et al (2001) Obesity prevalence and trends in Latin American countries. Obes Rev 2:99-106

13. Navarro A, Osella AR, Guerra V, Muñoz SE, Lantieri MJ, Eynard AR (2001) Reproducibility and validity of a Food-Frequency Questionnaire in assessing dietary intakes and food habits in epidemiological cancer studies in Argentina. J Exp Clin Cancer Res 20:365-370

14. Navarro A, Cristaldo PE, Díaz MP, Eynard AR (2000) Atlas fotográfico para cuantificar el consumo de alimentos y nutrientes en estudios nutricionales epidemiológicos en Córdoba, Argentina. Rev Fac Cienc Méd Córdoba 57:67-74

15. Peyrano MG, Gigena JC, Muñoz SE et al (1998) A computer software for the analysis of dietary data in cancer epidemiological research. In: Moraes M, Brentani R, Bevilacqua R (eds) International proceeding division. Monduzzi Editore, Bologna, pp 381-384

16. Internacional Physical Activity Questionnaire (IPAQ) (2005). http://www.ipaq.ki.se/ipaq.htm. Accessed 21 May 2013

17. Asociación Argentina de Marketing, Cámara de Control y Medición de Audiencias (2003) Índice del nivel socioeconómico 2002. http://www.iprofesional.cpm/adjuntos/documentos/18/0001836.pdf. Accessed 12 July 2014

18. National Academy of Sciences, Institute of Medicine, Food and Nutrition Board (2004) Dietary reference intakes (DRIs): macronutrients. National Academy of Sciences, Institute of Medicine, Food and Nutrition Board, Washington, DC

19. National Academy of Sciences, Institute of Medicine, Food and Nutrition Board (2004) Dietary reference intakes (DRIs): tolerable upper intake levels. National Academy of Sciences, Institute of Medicine, Food and Nutrition Board, Washington, DC

20. Stata Statistical Software, versión 12. StataCorp LP (2011) College Station, TX 77845, USA

21. Braguinsky J, Sereday M, Cobeñas C et al (1998) Unexpected prevalence of obesity and associated metabolic risk factors in a medium size city (Venado Tuerto) of Argentina. Int $\mathbf{J}$ Obes $22: 215 \mathrm{~s}$

22. De Loredo L, Luquez H, Madoery R et al (1997) Hypertension prevalence in the Dean Funes Communitary Study. Hypertension 29:846 
23. Ministerio de Salud, Presidencia de la Nación (2009). Encuesta Nacional de Nutrición y Salud. http://www.msal.gov.ar/htm/site/ ennys/pdf/documento_resultados_2007.pdf. Accessed 11 July 2013

24. Ministerio de Salud, Presidencia de la Nación (2011). Segunda Encuesta Nacional de Factores de Riesgo para Enfermedades No Transmisibles. http://www.msal.gov.ar/ent/images/stories/ vigilancia/pdf/fr_encuesta-nacional-factores-riesgo-2011.pdf. Accessed 11 July 2013

25. World Health Organization (WHO) (2013) The WHO Global InfoBase. https://apps.who.int/infobase/. Accessed 2 Aug 2014

26. World Health Organization (WHO) (2010) The Global Health Observatory program. http://www.who.int/gho/en/. Accessed 29 Aug 2013

27. Organización Panamericana de la Salud (OPS) (2003) Régimen alimentario, nutrición y actividad física. 132a. Sesión del Comite Ejecutivo. Washigton, pp 23-27

28. Aranceta J, Pérez Rodrigo C, Serra Majem L, Ribas Barba L, Quiles Izquierdo J, Vioque J (2003) Prevalencia de la obesidad en España: resultados del estudio SEEDO 2000. Med Clin (Barc) 120:608-612

29. Sánchez Villegas A, Martínez González MA, Toledo E, De Iral EstévezJ, Martínez JA (2002) Influencia del sedentarismo y el hábito de comer entre horas sobre la ganancia de peso. Med Clin (Barc) 119:46-52

30. Lino MZ, Muniz PT, Siqueira KS (2011) Prevalence of overweight and associated factors in adults: a population survey in Rio Branco, Acre State, Brazil, 2007-2008. Cad. Saúde Pública 27:797-810

31. Arsenault BJ, Rana JS, Lemieux I, Després JP, Kastelein JJ, Boekholdt SM, Wareham NJ, Khaw KT (2010) Physical inactivity, abdominal obesity and risk of coronary heart disease in apparently healthy men and women. Int J Obes (Lond) 34:340 347. doi:10.1038/ijo.2009.229

32. Choi B, Schnall PL, Yang H, Dobson M, Landsbergis P, Israel L, Karasek R, Baker D (2010) Sedentary work, low physical job demand, and obesity in US workers. Am J Ind Med 53:10881101. doi:10.1002/ajim.20886

33. Varo Cenarruzabeitia JJ, Martínez Hernández JA, MartínezGonzález MA (2003) Beneficios de la actividad física y riesgos del sedentarismo. Med Clin (Barc) 121:665-672

34. Berg C, Lappas G, Wolk A, Strandhagen E, Torén K, Rosengren A, Thelle D, Lissner L (2009) Eating patterns and portion size associated with obesity in a Swedish population. Appetite 52:2126. doi:10.1016/j.appet.2008.07.008

35. Jeon KJ, Lee O, Kim HK, Han SN (2011) Comparison of the dietary intake and clinical characteristics of obese and normal weight adults. Nutr Res Pract 5:329-336. doi:10.4162/nrp.2011.5.4.329

36. Vadera BN, Yadav SB, Yadav BS, Parmar DV, Unadkat SV (2010) Study on obesity and Influence of dietary factors on the weight status of an adult population in Jamnagar city of Gujarat: a cross-sectional analytical study. Indian J Community Med 35:482-486. doi:10.4103/0970-0218.74346

37. Singh R, Martin BR, Hickey Y, Teegarden D, Campbell WW, Craig BA, Schoeller DA, Kerr DA, Weaver CM (2009) Comparison of self-reported, measured, metabolizable energy intake with total energy expenditure in overweight teens. Am J Clin Nutr 89:1744-17450. doi:10.3945/ajcn.2008.26752

38. Stubbs CO, Lee AJ (2004) The obesity epidemic: both energy intake and physical activity contribute. Med J Aust 181:489-491

39. Bray GA, Paeratakul S, Popkin BM (2004) Dietary fat and obesity: a review of animal, clinical and epidemiological studies. Physiol Behav 83:549-555

40. Willett WC (2002) Dietary fat plays a major role in obesity: no. Obes Rev 3(2):59-68

41. Kimokoti RW, Newby PK, Gona P, Zhu L, Jasuja GK, Pencina MJ, McKeon-O'Malley C, Fox CS, D'Agostino RB, Millen BE
(2010) Diet quality, physical activity, smoking status, and weight fluctuation are associated with weight change in women and men. J Nutr 7:1287-1293. doi:10.3945/jn.109.120808

42. Aller EE, Abete I, Astrup A, Martinez JA, Baak MAV (2011) Starches, sugars and obesity. Nutrients 3:341-369

43. Murtaugh MA, Herrick JS, Sweeney C, Baumgartner KB, Giuliano AR, Byer T et al (2007) Diet composition and risk of overweight and obesity in women living in the southwestern United States. J Am Diet Assoc 107:1311-1321

44. Organización de las Naciones Unidas (2011) Organización de las Naciones Unidas, Dirección de Estadística. http://faostat.fao.org/ site/368/DesktopDefault.aspx?PageID=368\#ancor. Accessed 18 Oct 2013

45. Navarro A, Muñoz SE, Lantieri MJ, Fabro EA, Eynard AR (1997) Composition of saturated and unsaturated fatty acids of foods frequently consumed in Argentina. Arch Latinoam Nutr 47:276-281

46. Instituto de Promoción de la carne vacuna Argentina (2014) Informe de Faena y producción de carne vacuna $3^{\circ}$ trimestre 2014. https://www.ipcva.com.ar/documentos/1348_1412870500_informedefaenayproduccin3trimestre2014.pdf. Accessed 20 Nov 2014

47. Major GC, Chaput JP, Ledoux M et al (2008) Recent developments in calcium-related obesity research. Obes Rev 9:428-445. doi:10.1111/j.1467-789X.2007.00465.x

48. Ness AR, Smith GD, Hart C (2001) Milk, coronary heart disease and mortality. J Epidemiol Community Health 55:379-382

49. Belury MA (2002) Dietary conjugated linoleic acid in health: physiological effects and mechanisms of action. Annu Rev Nutr 22:505-531. doi:10.1146/annurev.nutr.22.021302.121842

50. Layman DK (2002) Role of leucine in protein metabolism during exercise and recovery. Can J Appl Physiol 27:646-663

51. Pereira MA, Jacobs DR Jr, Van Horn L, Slattery ML, Kartashov AI, Ludwig DS (2002) Dairy consumption, obesity, and the insulin resistance syndrome in young adults: the CARDIA Study. JAMA 287:2081-2089

52. Lourenco S, Olivera A, Lopes C (2012) The effect of current and life time alcohol consumption on overall and central obesity. Eur J Clin Nutr 66:813-818. doi:10.1038/ejen.2012.20

53. Bouche C, Rizkalla SW, Luo J, Vidal H, Veronese A, Pacher N et al (2002) Five-week, low-glycemic index diet decreases total fat mass and improves plasma lipid profile in moderately overweight nondiabetic men. Diabetes Care 25:822-828

54. Lema S, Longo E, Lopresti A (2002) Guías Alimentarias: Manual de multiplicadores, 1ra edn. Asociación Argentina de Nutricionistas y Dietistas, Argentina, p 56

55. Soto D, Wittig E, Guerrero L, Garrido F, Fuenzalida R (2006) Alimentos funcionales: comportamiento del consumidor chileno. Rev Chil Nutr 33:43-54

56. Brand Miller J, McMillan Price J, Steinbeck K, Caterson I (2009) Dietary glycemic index: health implications. J Am Coll Nutr 28:446-449

57. Lin BH, Morrison RM (2002) Higher fruit consumption linked with lower body mass index. Food Rev 25:28-32

58. Ledikwe JH, Blanck HM, Kettel KL, Serdula MK, Seymour JD, Tohill BC et al (2006) Dietary energy density is associated with energy intake and weight status in US adults. Am J Clin Nutr 83:1362-1368

59. Groth MV, Fagt S, Stockmarr A, Matthiessen J, Biltoft-Jensen A (2009) Dimensions of socioeconomic position related to body mass index and obesity among Danish women and men. Scand $\mathbf{J}$ Public Health 37:418-426

60. Nasreddine L, Hwalla N, Sibai A, Hamze M, Parent Massin D (2006) Food consumption patterns in an adult urban population in Beirut, Lebanon. Public Health Nutr 9:194-203

61. Ribas-Barba L, Serra-Majem L, Salvador G, Castell C, Cabezas C, Salleras L et al (2007) Trends in dietary habits and food 
consumption in Catalonia, Spain (1992-2003). Public Health Nutr 10:1340-1353. doi:10.1017/s136898000700095X

62. Malik VS, Schulze MB, Hu FB (2006) Intake of sugar-sweetened beverages and weight gain: a systematic review. Am J Clin Nutr 84:274-288

63. Sacks FM, Bray GA, Carey VJ, Smith SR, Ryan DH, Anton SD, Mc Manus K, Champagne CM, Bishop LM, Laranjo N et al (2009) Comparison of weight-loss diets with different compositions of fat, protein, and carbohydrates. N Engl J Med 360:859873. doi:10.1056/NEJMoa0804748

64. Van Dam RM, Seidell JC (2007) Carbohydrate intake and obesity. Eur J Clin Nutr 61:75-99. doi:10.1038/sj.ejcn.1602939

65. Bray GA (2008) Fructose-How worried should we be? Medscape J Med 10:159

66. Bray GA, Nielsen SJ, Popkin BM (2004) Consumption of highfructose corn syrup in beverages may play a role in the epidemic of obesity. Am J Clin Nutr 79:537-543

67. Bantle JP (2009) Dietary fructose and metabolic syndrome and diabetes. J Nutr 139:1263S-1268S. doi:10.3945/jn.108.098020
68. Ghosh A, Bose K, Das Chaudhuri AB (2003) Association of food patterns, central obesity measures and metabolic risk factors for coronary heart disease (CHD) in middle aged Bengali Hindu men, Calcutta, India. Asia Pac J Clin Nutr 12:166-171

69. Ovaskainen ML, Reinivuo H, Tapanainen H, Hannila ML, Korhonen T, Pakkala H (2006) Snacks as an element of energy intake and food consumption. Eur J Clin Nutr 60:494-501. doi:10.1038/sj.ejcn.1602343

70. Jackson P, Romo MM, Castillo MA, Castillo-Durán C (2004) Junk food consumption and child nutrition. Nutritional anthropological analysis. Rev Med Chil 132:1235-1242

71. Blood AJ, Zatorre RJ (2001) Intensely pleasurable responses to music correlate with activity in brain regions implicated in reward and emotion. Proc Natl Acad Sci USA 98:11818-11823. doi:10.1073/pnas.191355898

72. Drewnowski A, Specter S (2004) Poverty and obesity: the role of energy density and energy costs. Am J Clin Nutr 79:6-16

73. Rothman KJ, Greenland S, Lash TL (2008) Modern Epidemiology, 3rd edn. Lippincott Williams \& Wilkins, USA 